\title{
Supervised mediocrity
}

\author{
Stephen Hancocks OBE \\ Editor-in-Chief
}

\author{
Send your comments to the \\ Editor-in-Chief \\ British Dental Journal \\ 64 Wimpole Street, \\ London \\ W1G 8YS \\ Email bdj@bda.org
}

It is not often that I get the unusual circumstance to land on so many doormats on Christmas Eve. It is fortuitous because it provides me with the perfect opportunity to wish you a very timely Merry Christmas. Having written that, I imagine that the vast majority of readers will be far too busy doing much more important festive things than spending time opening and reading the $B D J$. There is no blame attached to this in the least part but in which case, I hope that you are reading this after having enjoyed a wonderful holiday break.

Given the above, it might seem somewhat churlish of me to say that I worry. I worry less than I used to, indeed those who know me even fleetingly might be surprised to read this, supposing instead that from an otherwise calm exterior there would be little to cause concern. I remember as a teenager being a terrible worrier, everything troubled me, and I imagine many of my contemporaries were the same, although one would never be so puny as to admit it. Me worry? No, how un-cool is that? I even worried when I had nothing particular to worry about, fearing that I might be overlooking something that should be causing me torment.

\section{A LONG, LOW RUMBLING UNEASE}

To put your mind at ease the worries I have now are not as acute as then, nor as dramatic but instead form a long, low rumbling unease about the way things are going in dentistry. On the one hand there has probably never been a potentially more exciting time to be launching into the profession and I know many young graduates who are eagerly getting to grips not only with the new realities of dentistry in an age of economic downturn and NHS reform but also contemplating the horizons opening up in the wider fields of oral healthcare within general healthcare; aesthetic, holistic and realistic. Yet on the other hand I see, read and hear from a lot of very experienced, very respected and very fed-up colleagues who are being brought down by the sheer welter of bureaucracy, regulation and, as they see it, interference in their practising lives.

There is a tendency to greet the cry of 'it never used to be like this' with an equally compelling response such as 'wake up and smell the coffee', 'get real' or 'welcome to the twentyfirst century' and to some extent there is truth there too. But at the heart of this is, I believe, a greater if not entirely intentional movement which is having the effect of driving what can only be termed a supervised mediocrity. As I have written here many times recently I am not in the least advocating that we should abandon safety or deny sensible (and preferably evidence-based) improvements but I am similarly advocating that for all the politically correct impositions we should also reflect on what might be quaintly termed the 'art of dentistry' which is, after all, some fifty percent of what the activity is supposed to be about.

The art might be the ability to sculpt lovely cusps in composite, it might be about the skill in creating beautiful dentures but it is almost certainly about building patient confidence and respect and by so doing helping to improve their health and wellbeing. The problem is that it does not easily lend itself to tick-box reportage. In the last few days, someone has said of the Euro currency that the recent attempts to support it have been like preserving the cancer while letting the patient die. Irrespective of one's political or economic view the simile is striking. Although far less dramatic in relation to good dental practice, it is tempting to highjack the sentiment and worry that while the powers that be are busy making sure our practices are germ free, quality controlled and secured against every possible danger to the public they might just have overlooked the possibility that the living, breathing entity underneath it all is being suffocated. Authors of the many letters and emails received at the journal, and far too many to publish (but please don't let that deter any one of you) keep returning to the points that their patients love what they provide, that they haven't had a single epidemic centred on their practice in the half-century that it has been established but that they are now thinking of giving it all up because they can no longer provide the care that has sustained them and their loyal followers for all those years.

So, that's why I worry. There will be the normal distribution of human endeavour represented within these musings; from the practices which arguably should give up the ghost through to those who might sell up and go into financial services or suchlike instead. But for the majority I believe there is a genuine frustration and actually a real sadness that the care they know works is increasingly likely to be stamped out by a progress that is fallacious. There is no doubt that young colleagues will inhabit the personas of their own practices and practises going forwards but the worry remains that we may be sacrificing the art for the science, or, actually, the illusion of science in the name of control.

DOI: $10.1038 / s j . b d j .2011 .1055$ 